\title{
Fungsi Representasi dalam Mengakses Penguasaan Konsep Fisika Mahasiswa
}

\author{
Murtono $^{1}$, Agus Setiawan ${ }^{2}$, Dadi Rusdiana ${ }^{2}$ \\ 'Pendidikan Fisika UIN Sunana Kalijaga Yogyakarta, \\ ${ }^{2}$ Pascasarjana UPI Bandung \\ Surat-e: hasnamur@yahoo.co.id
}

Fisika merupakan ilmu fenomena alam yang disajikan dalam bentuk gambaar, persamaan matematis, mempunyai hubungan antar variabel fisis. Untuk mengakses perlu karakteristik yang sesuai dengan ilmu fisika tersebut. Salah satu cara mengakses yang sesuai adalah dengan bentuk representasi. Repersentasi mempunyai fungsi sebagai pelengkap, membatasi interpretasi, dan membangun pemahaman. Telah dilakukan pengukuran terhadap penguasaan konsep mahasiswa Program Studi Pendidikan Fisika dengan soal multi representasi. Hasil menunjukkan bahwa jawaban yang benar bervariasi sesuai dengan konsep yang diukur dan mode representasi yang digunakan. Multirepresentasi dapat menjadi pelengkap representasi yang lain, membatasi interpretasi representasi yang lain, dan membangun pemahaman mahasiswa dalam menyelesaian permasalahan fisika, sesuai dengan fungsi representasi.

Kata kunci: multi representasi, konsistensi representasi, konsistensi ilmiah

\section{Pendahuluan}

Penguasaan konsep merupakan bagian yang sangat penting yang harus dimiliki oleh peserta didik ketika mempelajari fisika dan untuk memecahkan masalah-masalah fisika. Tujuan dari pembelajaran fisika adalah agar pebelajar memperoleh sejumlah konsep (a modust amount) dan menerapkan atau mengaplikasikan secara fleksibel (Reif, 1995:17). Mereka harus mengetahui tentang apa masalah tersebut, relevan dengan masalah fisika apa dan bagaimana menginterpretasikan hasilnya. Fisika adalah bagian dari ilmu pengetahuan alam yang mempunyai karakteristik tertentu. Menurut Wospakrik (I993:I) bahwa Fisika merupakan salah satu cabang ilmu pengetahuan alam yang bertujuan untuk mempelajari dan memberi pemahaman kuantitatif terhadap berbagai gejala atau proses alam dan sifat zat serta penerapannya. Fisika merupakan sains kuantitatif yang menggunakan matematika dalam mengungkapkan gagasangagasannya (Alonso \& Finn, 2000). Baiquni (t.t) menyatakan Ilmu Fisika adalan suatu cabang ilmu pengetahuan, dimana kita menyeliadiki sifat-sifat dan kelakuan alam dengan observasi dalam experimeneksperimen, dengan pengukuran-pengukuran dan analisa, sehingga dapat di temukan sifat-sifat fundamentil dari pada alam itu. Sifat dan kelakuan alam ini biasanya dinamakan hukum alam dan dirimusakan secara matematis, karena hubungan antara besaran-besaran fisis yang terukur kwantiatasnya dalam experimen itu hanya dapat dinyatakan dengan tegas dalam perumusan tersebut. Dengan sifat dasar ilmu fisika ini maka penguasaan konsep fisika akan tepat jika diases dengan soal multi representasi. Hal ini sejalan dengan pendapat Peter C. Gega dalam Sumaji dkk. (1998:I49) bahwa diantara ketrampilan IPA adalah ketrampilan menemukan keteraturan hubungan antarubahan, keterampilan menyajikan data dalam bentuk tabel dan grafik, ketrampilan menafsirkan data, dan ketrampilan berkomunikasi.

Untuk mengakses penguasaan konsep mahasiswa, diperlukan asesmen yang sesuai dengan karakter ilmu fisika tersebut. Asesmen pendidikan yang selama ini dilakukan oleh sebagian para pendidik tidak dapat diharapkan dapat berdampak terhadap efektifitas tercapainya tujuan pendidikan atau tujuan dari pembelajaran itu sendiri (Soedijarto, 2004:104). Sesuai dengan hasil penelitian 
Benyamin Bloom bahwa perkiraan peserta didik tentang apa yang akan diujikan berpengaruh terhadap tingkah laku belajar peserta didik. Agar peserta didik secra intensif dan terus menerus melakukan proses pembelajaran yang bermakna sejak memasuki suatu jenjang pendidikan, perlu dikembangkan dan dilaksanakan asesmen secara komprehensif, terus menerus dan obyektif sehingga membantu tercapainya berbagai tujuan pendidikan. Asesmen yang demikian hanya dapat dilakukan oleh seorang pendidik yang profesional yang mampu merencanakan, mengelola, memotivasi, dan menilai proses pembelajaran yang berlangsung secara tepat dari waktu ke waktu. Berkaitan dengan pendidikan fisika, Bascones (dalam Mansyur, 2009) menyatakan bahwa belajar fisika sama dengan pengembangan kemampuan problem solving dan pencapaian diukur dengan sejumlah masalah yang pebelajar dapat pecahkan secara tepat.Multi representasi menawarkan sebuah asesmen yang mengakses sebuah penguasaan konsep dalam bentuk yang berbeda berbeda representasinya.

Penelitian sebelumnya menunjukkan bahwa penyelesaian masalah (solved problem) dalam berbagai bentuk representasi, matematis, verbal, grafik dan gambar telah dilakukan untuk pokok bahasan mekanika (Meltzer, 2005). Kompetensi siswa dalam format representasi yang berbeda merupakan topik yang populer dalam pendidikan sains dan matematika moderen. Dengan format representasi yang mengacu pada banyak cara dimana suatu konsep tertentu atau masalah dapat dinyatakan (Kohl P.\&Noah D. F., 2007). Siswa dalam pembelajaran selalu mengingat informasi yang disampaikan oleh guru, sehingga dapat dengan mudah dimunculkan kembali dalam penyelesaian soal tanpa memahami maknanya. Selain itu kemampuan representasi yang dikembangkan dalam deskripsi verbal diubah kedalam bentuk representasi lain seperti: simbul, grafik, gambar, tabel, dan terkadang sebaliknya. Fisika sebagai sebuah mata pelajaran, dalam menguasainya dibutuhkan pemahaman dan kemampuan cara representasi yang berbeda-beda untuk satu konsep atau tema yang sama. Kemampuan siswa dalam menggunakan representasi dalam memahami fisika manjadi halangan pemahaman mereka (Gunel, Hand, dan Gunduz, 2006). Multi representasi mempunyai tiga fungsi utama yaitu sebagai pelengkap, pembatas interpretasi, dan pembentuk pengetahuan (Ainswort, 1999). Multi representasi sebagai pelengkap dalam proses berfikir dan kognitif siswa dalam mendapatkan konsep-konsep yang lebih sempurna. Selain itu dengan multi representasi dapat digunakan untuk membatasi kemungkinan-kemungkinan kesalahan dalam meginterpretasikan sebuah konsep, prinsip, dan hukumhukum fisika. Yang ketiga, multipel representasi digunakan untuk mendorong siswa membangun pemahaman terhadap situasi secara lebih mendalam.

Representasi merupakan proses pembentukan, abstraksi dan pendemonstrasian pengetahuan fisika. Representasi konsep, prinsip dan permasalahan kontekstual merupakan isu dalam pembelajaran dan asesmen dalam fisika. Model representasi yang digunakan sebagai asesmen dapat membantu pemahaman dan berkaitan dengan kesiapan seseorang. Selain membantu pemahaman, asesmen multi representasi seseorang menunjukkan kemampuannya dalam memecahkan masalah fisika. Suatu masalah yang dianggap rumit dan kompleks, bisa menjadi lebih sederhana jika strategi dan pemanfaatan representasi fisika digunakan dalam permasalahan tersebut.

\section{Metode Penelitian}

Data dalam penelitian diambil ini dengan metode ex post facto, yaitu mengambil data dari gejala-gejala yang sudah ada atau telah terjadi, sehingga tidak ada perlakuan. Penelitian ex post facto adalah suatu penelitian yang dilakukan untuk meneliti peristiwa yang telah terjadi dan kemudian merunut ke belakang untuk mengetahui faktorfaktor yang dapat menyebabkan timbulnya kejadian tersebut (Sugiyono, 2003:9). Pengambilan data dilakukan dengan memberikan tes multi representasi pilihan ganda yang sudah valid dan reliabel terhadap 40I mahasiswa Pendidikan Fisika yang telah mengambil mata kuliah Fisika Dasar I dari beberapa perguruan tinggi.

\section{Hasil dan Pembahasan}

\section{Representasi sebagai pelengkap}

Fungsi pertama dari representasi adalah sebagai pelengkap, atau membantu melengkapi proses kognitif dalam memecahkan permasalahan fisika. Sebuah konsep dapat dijelaskan secara verbal yaitu dengan teks atau kalimat yang dapat menjelaskan konsep, sehingga sebuah konsep dapat dipahami dan dikuasai oleh seorang pebelajar. Konsep akan lebih mudah dipahami jika dilengkapi dengan gambar, persamaan matematik yang menggambarkan hubungan antar variabel atau konsep. Selain gambar dan persamaan matematis hubungan antar variabel fisis juga dapat dijelaskan dengan sebuah grafik. Selanjutnya sebuah konsep juga dapat diases dengan representasi yang berbeda agar diperoleh informasi yang lebih lengkap. Sebagai contoh adalah konsep tentang kecepatan rata-rata untuk partikel yang bergerak lurus beraturan.

Soal dimulai dari sebuah pernyataan:"Sebuah partikel bergerak dengan kecepatan tetap dari titik A ke titik B 
kemudian ke titik C”. Dapat dibuat kedalam empat bentuk soal representasi sebagai berikut:

I. Representasi verbal: Manakah pernyataan berikut yang paling tepat?

a. Kecepatan rata-rata tergantung dari lintasan yang dilaluinya

b. Kecepatan rata-rata merupakan garis singgung dari kurva lintasan

c. Kecepatan rata-rata merupakan perbandingan antara jarak dengan waktu yang ditempuh

d. Kecepatan rata-rata tergantung pada perpindahan dan waktu tempuh

e. Kecepatan rata-rata tidak dipengaruhi oleh arah gerakan

2. Gambar: Gambar berikut adalah lintasan gerakan partikel, manakah partikel yang mempunyai kecepatan rata-rata paling besar untuk waktu yang sama?

a.

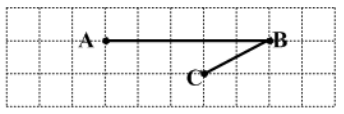

b.

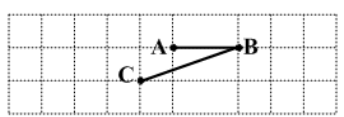

c.

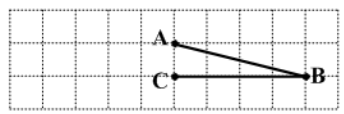

d.

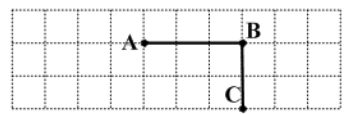

e.

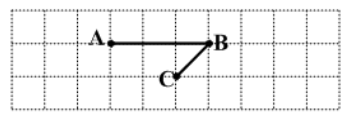

3. Kecepatan rata-rata partikel dalam pergerakan dapat dinyatakan sebagai berikut:
a. $\overline{\mathrm{v}}=\frac{\mathrm{X}_{\mathrm{C}}}{\mathrm{t}_{\mathrm{C}}}-\frac{\mathrm{X}_{\mathrm{A}}}{\mathrm{t}_{\mathrm{A}}}$
b. $\quad \bar{v}=\frac{x_{C}-x_{A}}{t_{C}-t_{A}}$
c. $\bar{v}=\frac{X_{C}-X_{B}}{t_{C}-t_{B}}+\frac{X_{B}-X_{A}}{t_{B}-t_{A}}$
d. $\quad \overline{\mathrm{V}}=\frac{\mathrm{dX}}{\mathrm{dt}}$
e. $\quad \bar{v}=\lim _{\Delta t \rightarrow 0} \frac{\Delta X}{\Delta t}$

4. Manakah grafik gerak dari A ke C yang menujukkan kecepatan rata-rata paling tinggi? a.

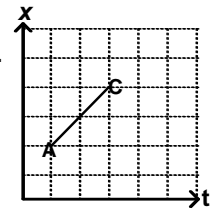

d.

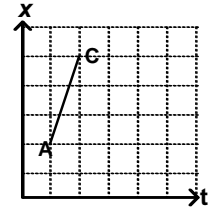

b.
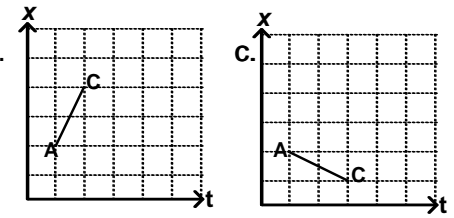

Keempat soal representasi diatas mengandung satu konsep yang diukur, yaitu kecepatan rata-rata sebuah partikel yang bergerak lurus beraturan. Jika pada pernyataan verbal seorang pebelajar bisa mengungkapkan definisi dari kecepatan rata-rata secara benar, belum tentuk dapat menjawab representasi yang lain. Contoh kasus: Seorang pebelajar menjawab untuk representasi verbal:"Kecepatan rata-rata tergantung pada perpindahan dan waktu tempuh", namun pada representasi gambar pengecoh yang paling berfungsi adalah option (c):

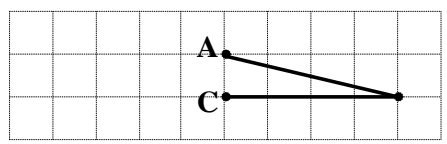

Jawaban ini dapat diinterpretasikan sebagai perpindahan partikel dari A ke C mempunyai kecepatan rata-rata yang paling tinggi adalah partikel yang mempunyai perpindahan yang paling kecil. Pada representasi verbal belum nampak bagaimana hubungan antara perpindahan dengan waktu tempuhnya. Selain itu dari option pengecoh yang paling berfungsi menunjukkan bahwa seorang pebelajar menganggap semakin kecil perpindahan, semakin semakin besar kecepatan rata-ratanya. Struktur kognitif yang ada pada pebelajar bahwa semakin kecil perpindahan kecepatan rata-rata semakin besar. Penyebab dari jawaban ini dimungkinkan seorang pebelajar hafal dengan definisi tersebut, namun tidak memahami makna dari kecepatan rata-rata, sehingga ketika dihadapkan soal dalam bentuk representasi yang lain akan mengalami kesulitan dalam menjawabnya. 
Pada representasi matematik, pengecoh yang paling berfungsi adalah otion (d) yaitu: $\overline{\mathrm{v}}=\frac{\mathrm{dX}}{\mathrm{dt}}$. Option ini merupakan bentuk persamaan matematik yang menggambarkan kecepatan sesaat partikel yang bergerak lurus beraturan. Jika seorang pebelajar menguasai konsep tersebut maka tidak akan ada kesalahan dalam memilih jawaban. Oleh karena itu multi representasi menjadi pelengkap informasi jawaban pebelajar dalam menyelesaikan permasalahan fisika. Hasil pengukuran terhadap $40 \mathrm{I}$ mahasiswa yang telah mengambil mata kuliah Fisika Dasar I ditunjukkan pada tabel 3.I.

Tabel 3.I. Profil Jawaban Mahasiswa Pendidikan Fisika dalam Menyelesaiakan Masalah Fisika Berdasar Representasi

\begin{tabular}{|c|c|c|c|c|c|}
\hline \multirow{2}{*}{ Konsep } & \multicolumn{4}{|c|}{$\begin{array}{c}\text { Persentase Jumlah Mahasiwa yang } \\
\text { Menjawab Benar (\%) } \\
\end{array}$} & \multirow{2}{*}{$\begin{array}{c}\text { Rata- } \\
\text { rata } \\
\text { Setiap } \\
\text { Topik } \\
(\%)\end{array}$} \\
\hline & Verbal & Gambar & $\begin{array}{l}\text { Mate- } \\
\text { matis }\end{array}$ & Grafik & \\
\hline $\begin{array}{l}\text { Kecepatan } \\
\text { Rata-rata }\end{array}$ & 56,8 & 40,6 & $43, I$ & 69,3 & 52,4 \\
\hline Gerak Parabola & 37,9 & 49,8 & 21,6 & 50,6 & 40,0 \\
\hline Resultan Gaya & 65,3 & 66,3 & 42,8 & $52, \mathrm{I}$ & 56,6 \\
\hline $\begin{array}{l}\text { Hukum I, } \\
\text { II,III Newton }\end{array}$ & 48,3 & 57,6 & 67,5 & 46,6 & 55,0 \\
\hline $\begin{array}{l}\text { Hukum } \\
\text { Kekekalan } \\
\text { Energi }\end{array}$ & 60,0 & 60,0 & 65,0 & 66,3 & 63,0 \\
\hline Usaha & $4 \mathrm{I}, 3$ & 67,5 & $53, \mathrm{I}$ & 60,5 & 55,6 \\
\hline $\begin{array}{l}\text { Rata-rata } \\
\text { Setiap } \\
\text { Representasi }\end{array}$ & $5 I, 6$ & $57, \mathrm{I}$ & 48,9 & 56,6 & 53,8 \\
\hline
\end{tabular}

Tabel 3.I dapat dijelaskan bahwa masing-masing pokok bahasan/sub pokok bahasan mempunyai pola jawaban mahasiswa dalam menjawab soal multi representasi berbedabeda. Secara umum persentase tertinggi terdapat pada kecepatan rata-rata representasi grafik yang besarnya $69,3 \%$, sedangkan skor terendah ada pada pokok bahasan gerak parabola representasi matematik dengan skor 21,6\%. Hasil persentase rata-rata mempunyai nilai $53,8 \%$, nilai ini adalah merupakan nilai rata-rata kelompok peserta tes, yang besarnya sama dengan nilai rata-rata tingkat kesukaran soal. Untuk masing-masing modus representasi dan topik mempuanyai banyak variasi dan tidak ada pola tertentu. Terdapatnya variasi ini karena beberapa faktor diantaranya karakteristik masing-masing soal, karakteristik topik, karakteristik representasi dan variasi kemampuan masingmasing mahasiswa. Diantara masing-masing representasi mempunyai informasi yang melengkapi terhadap representasi yang lain.

\section{Representasi pembatas Interpretasi}

Representasi berfungsi untuk membatasi kemungkinan kesalahan dalam menginterpretasi dalam menggunakan interpretasi yang lain. Dapat digunakan untuk menggali sifat-sifat inheren satu representasi untuk membatasi representasi yang lain. Pada konsep jarak dan konsep perpindahan terdapat miskonsepsi, dan ini akan berakibat pada miskonsepsi konsep laju dan kecepatan, karena ada hubungan yang sangat erat antara keduanya. Jika konsep jarak dan perpindahan ini dinyatakan dengan gambar maka akan sangat jelas perbedaanya. Pada gambar berikut adalah gambar gerak partikel dari A ke B kemudian ke C.

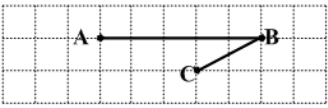

(a) (b)
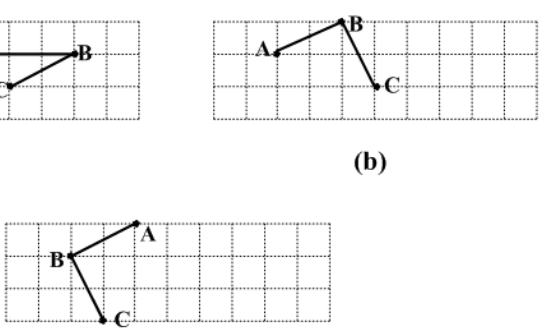

(c)

Antara gambar (a) dengan gambar (b) merupakan perpindahan partikel dengan lintasan yang berbeda tetapi harga perpindahannya adalah sama, hal ini dapat dilihat dari posisi awal dengan posisi akhirnya. Kita ambil posisi awal A adalah titik $(0,0)$, maka untuk vektor dua dimensi perpindakan dari gerak tersebut dapat dinyatakan sebagai $\overrightarrow{A C}=3 \hat{\imath}-\hat{\jmath}$. Kedua gambar tersebut akan mempunyai kecepatan rata-rata yang besarnya sama untuk waktu tempuh yang sama. Akan tetapi kedua gerak tersebut mempunyai panjang lintasan yang berbeda, dengan kata lain jarak tempuh yang berbeda pula, sehingga laju dari kedua gerakan tersebut addalah berbeda. Untuk gambar (b) dengan gambar (c) mempunyai panjang lintasan atau jarak tempuh yang sama sehingga mengakibatkan laju dari kedua gerak tersebut sama. Akan tetapi jika perpindahan dari gerakan tersebut berbeda atau mempunyai kecepatan ratarata berbeda untuk waktu tempuh yang sama. Secara vektor untuk gambar (b) mempunyai perpindahan $\overrightarrow{A C}=3 \hat{\imath}-\hat{\jmath}$ dan untuk gambar (c) mempunyai perpinahan $\overrightarrow{A C}=-\hat{\imath}-$ $3 \hat{\jmath}$. Jika dilihat dari besar dari vektor pergeseran maka ketiga gerakan tersebut mempunyai besar $|\overrightarrow{A C}|=\sqrt{10}$. Jika seorang pebelajar mengusai betul konsep jarak, perpindahan, 
laju maupun kecepatan maka tidak akan salah dalam menjelaskan ketiga gerakan tersebut. Hal ini dapat dibantu dengan menggunakan gambar maupun persamaan matematik sehingga konsep-konsep yang inheren dapat dibatasi, hal ini merupakan bagian dari fungsi representasi.

\section{Representasi sebagai pembangun}

Multiepresentasi dapat digunakan untuk membangun pemahaman yang lebih mendalam yaitu meningkatkan abstraksi, membangun hubungan antar representasi, dan membantu generalisasi. Sebuah konsep yang bersifat abstrak dapat dibuat lebih kongkrit dalam sajian gambar. Dapat dilihat kembali pada gambar berikut:

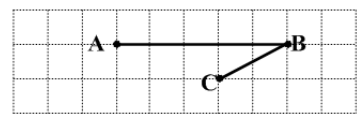

(a)

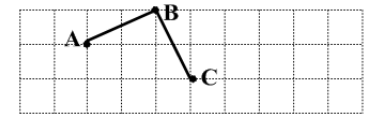

(b)
Dua gambar berikut akan membedakan konsep jarak dan perpindahan, sebagian dari pebelajar memahaminya dengan abstrak tentang jarak dan perpindahan, namun dengan melihat lintasan dan posisi kedua gerakan dari gambar (a) dan (b), konsep jarak dan perpindahan dapat dipahami secara lebih mudah. Hubungan antar representasi dapat dilihat dari masing-masing soal yang mengukur konsep yang sama untuk modus representasi yang berbeda. Hal ini membutuhkan kemampuan untuk mentransformasi antar modus representasi. Selanjutnya dari masing-masing reoresentasi yang diperoleh dapat digunakan untuk menarik sebuah kesimpulan atau membuat generalisai tentan konsep yang diukur.

\section{Kesimpulan}

Dalam penelitian ini dilakuan uji terhadap mahasiswa Pendidikan Fisika yang telah mengambil mata kuliah Fisika Dasar I. Hasil yang diperoleh bahwa besarnya persentase jawaban yang benar bervariasi sesuai dengan konsep-konsep yang diukur dan mode representasi. Hal ini karena satu konsep diukur dengan empat soal tes yang berbeda representasi. Multi representasi dapat berfungsi sebagi pelengkap representasi yang lain, membatasi repesentasi yang laian dan membangun pemahaman yang lebih mendalam.

\section{Saran}

Dengan multi representasi yang baik dalam pembelaajaran maka konsep yang disampaikan kepada peserta didik akan sesuai dengan struktur kognitif yang ada pada peserta didik. Untuk itu perlu diperhatikan jenis representasi yang perlu disampaikan kepada peserta didik dalam menyusun, merencanakan, melaksanakan, dan mengevaluasi pembelajaran.

\section{Kepustakaan}

Ainsworth, S. 1999. "The Functions of Multiple Representations”. Computers \& Education, 33, I3II52

Alonso \& Finn. (2000). Dasar-dasar Fisika Universitas (alih bahasa: Lea Prasetyo dan Kusnul Hadi). Jakarta: Penerbit Erlangga.

Baiquni A. (t.t). Pengetahuan Tentang Struktur Materi Sebagai Pendorong Kemadjuan Masjarakat Modern. Pidato Pengukuhan Guru Besar UGM. [Online] Tersedia:

http://mgb.ugm.ac.id/media/download/pidatopengukuhan?download $=78 \% 3$ Aachmad-baiquni

Mansyur, J. (2010). Kajian Fenomenografi Aspek-aspek Model Mental Subyek Lintas Akademik dalam Problem Solving Konsep Dasar Mekanika. Disertasi: Tidak dipublikasikan

Meltzer E. D.(2005). Relation Between Students' ProblemSolving Performance and Representational Format. American Journal Physics 73 (5),

Reif, F. (1995). Millikan Lecture 1994: "Understunding and Teaching Important Scientific Thought Processes". American Journal Physics. 63, (I), 17-32

Soedijarto (2004). Kurikulum, Sistem Evaluasi, dan Tenaga Pendidikan sebagai Unsur Strategis dalam Penyelenggaraan Sistem Pengajaran Nasional, Jurnal Pendidikan Penabur, 03 hlm. 89-107

Sugiyono, (2008). Metode Penelitian Kunatitatif Kualitatif dan R\&D. Bandung. Alfabeta

Sumaji, et al. (1998). Pendidikan Sains yang Humanistis. Yogyakarta: Kanisius

Wospakrik, H.J. dan Hendrajaya, L. (1993). Dasar-dasar Matematika untuk Fisika. Jakarta : Ditjen Dikti Depdikbud RI Proyek Pembinaan Tenaga Kependidikan Pendidikan Tinggi. 